\title{
Conceptual modelling of human resource evaluation process
}

\author{
Doina Olivia Negoiţă ${ }^{1}$, Anca Alexandra Purcărea $^{1}$, Andreea Dumitrescu ${ }^{1, *}$, and Andronicus \\ Torp ${ }^{1}$
}

${ }^{1}$ Faculty of Entrepreneurship, Business Engineering and Management, Department of Management, University POLITEHNICA of Bucharest, 313 Independenţei Street, 060042, Romania

\begin{abstract}
Taking into account the highly diverse tasks which employees have to fulfil due to complex requirements of nowadays consumers, the human resource within an enterprise has become a strategic element for developing and exploiting products which meet the market expectations. Therefore, organizations encounter difficulties when approaching the human resource evaluation process. Hence, the aim of the current paper is to design a conceptual model of the aforementioned process, which allows the enterprises to develop a specific methodology. In order to design the conceptual model, Business Process Modelling instruments were employed - Adonis Community Edition Business Process Management Toolkit using the ADONIS BPMS Notation. The conceptual model was developed based on an in-depth secondary research regarding the human resource evaluation process. The proposed conceptual model represents a generic workflow (sequential and/ or simultaneously activities), which can be extended considering the enterprise's needs regarding their requirements when conducting a human resource evaluation process. Enterprises can benefit from using software instruments for business process modelling as they enable process analysis and evaluation (predefined / specific queries) and also model optimization (simulations).
\end{abstract}

\section{Introduction}

The evolution of the organizational structures, along with the increased complexity of roles and responsibilities undertaken by employees have generated the utter need for enterprises to develop an integrated system to exploit human resource talent [1]. Within this context, the concept of "human resource management" has emerged and continuously developed ever since, due to the strategic role of human capital in terms of professional and behavioural attributes [2-3]. The pressure to create and improve a system to focus on employees as a key resource for achieving organisational performance, has highlighted the importance of HR assessment.

The definition of "performance" takes different forms, depending on the subject it relates with, however, regarding human resource, the concept refers to the degree of accomplishment of a task in terms of "accuracy, completeness and efficiency" [4]. Hence, it is related to

${ }^{*}$ Corresponding author: dumidreea@gmail.com 
specific performance standards and organization's expectations regarding employee's ability to achieve them.

\section{Methodology}

Based on the underlying concepts of human resource management, the authors have proposed a conceptual model of the aforementioned process with three alternative paths. The conceptual model is focused on the employees' performance evaluation sub-process, for which an in-depth analysis is provided. Therefore, the methodology of the current paper consists of workflow design using Business Process Modelling instruments - Adonis Community Edition Business Process Management Toolkit based on ADONIS BPMS Notation. The modelling software enables retrieving an integrated view of the human resource management, including: activities, risks, objectives, information and knowledge.

\section{Conceptual model of human resource performance evaluation process}

\subsection{Integrated overview of human resource management model}

The sequence flow contained by the human resource management model (Fig.1) [5] starts by performing the first activity "Analyse the human resource requirements within the enterprise". This task allows for continuing the process based on the current level of existing employees, which is assessed within the decisional node "Existing employees (E) vs. Required employees $(R)$ ?". Hence, the enterprise should analyse their requirements in terms of human resource and follow the path which is according to their needs.

The first path corresponds to an equilibrium between the number of existing and required employees, which ends the process, respectively the End Event. When the number of current personnel exceeds the enterprise's needs in terms of human resource, then the second path is selected and the task "Dismiss employees" is executed. However, the enterprise may require more employees, which involves considering the third path, which comprises the following sub-processes: "Recruit", "Select", "Guide", "Train" employees and "Evaluate employees" [6-7].

The workflow of the latter sub-process is described in detail in section 3.2. Hence, based on the results emerging from human resource performance assessment, the model is divided into two paths, respectively the decisional node "What are the evaluation results?" is executed. Favourable results of the evaluation allow for keeping the employee within the enterprise, hence the opportunities for carrier development are thoroughly analysed in order to identify whether the employee is better suited for a higher job position, if available.

The decision of advancing the employee on the job hierarchy is retrieved from the decisional node "Should the employee be promoted?", which retrieves the current status of vacancies and carrier development opportunities within the organisation. Therefore, either "Promote employee" or "Maintain the employee on current position ", the enterprise should provide training assistance in order to continuously improve the personnel's performance. The unfavourable results generated by the assessment sub-process mark the end of the model as the task "Dismiss employee" is fulfilled. 


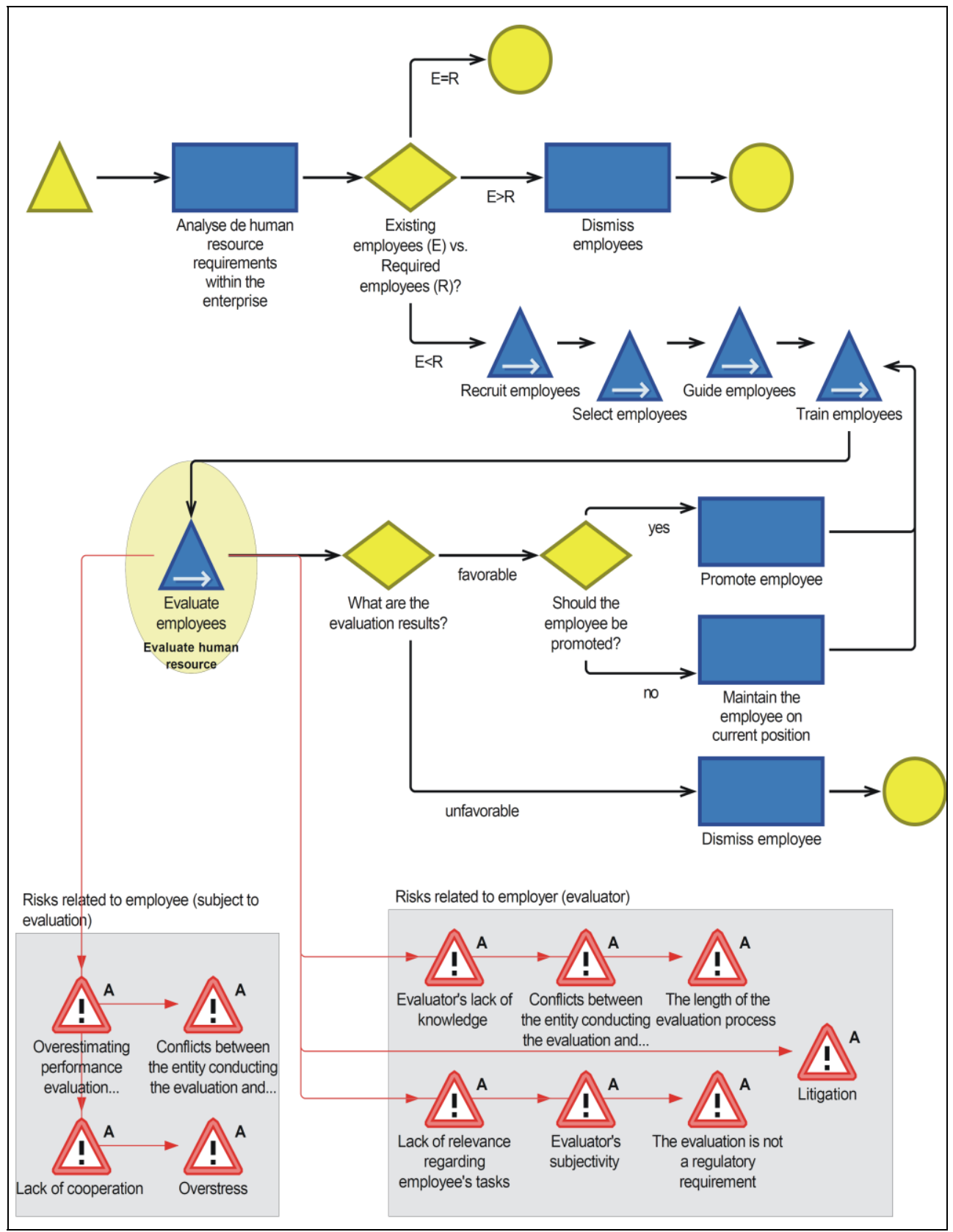

Fig. 1. Conceptual model of human resource management process.

When conducting the performance evaluation sub-process, both the employee and the employer are subject to different risks, which are depicted in Fig. 1 and described in Table 1. Understanding the risks related to the assessment activities has a crucial role, as it facilitates acknowledging the multiple factors which may influence the results of the human resource evaluation. 
Table 1. Risks related to human resource performance evaluation [8-11].

\begin{tabular}{|c|c|c|}
\hline No. & Risk & Description \\
\hline R1. & $\begin{array}{l}\text { Overestimating } \\
\text { performance evaluation } \\
\text { (employees' } \\
\text { opportunism) }\end{array}$ & $\begin{array}{l}\text { The employee has a tendency to change behaviour when the } \\
\text { evaluation due date is approaching (the employee works } \\
\text { longer hours; shows more interest in work results etc.). }\end{array}$ \\
\hline $\mathrm{R} 2$. & $\begin{array}{l}\text { Conflicts between the } \\
\text { entity conducting the } \\
\text { evaluation and the } \\
\text { employee subject to } \\
\text { evaluation }\end{array}$ & $\begin{array}{l}\text { Employees consider the evaluation results as criticism, as } \\
\text { opposed to an opportunity to identify and further improve } \\
\text { current weaknesses. } \\
\text { The evaluators focus on negative points. } \\
\text { The employees are biased regarding the aim of the } \\
\text { evaluation (they link the performance appraisal with a } \\
\text { negative event as they consider the evaluation results are } \\
\text { undervaluing the real job effort and accomplishments) }\end{array}$ \\
\hline $\mathrm{R} 3$ & Lack of cooperation & $\begin{array}{l}\text { The employee is not motivated to contribute to the appraisal/ } \\
\text { does not understand the importance (the added value) of the } \\
\text { evaluation. } \\
\text { Lack of communication between the assed and assessor / } \\
\text { poor feedback (the employee does not understand the } \\
\text { evaluation's results and/or the employee does not receive } \\
\text { specific details regarding his current rating). }\end{array}$ \\
\hline $\mathrm{R} 4$ & Overstress & $\begin{array}{l}\text { The employees become too preoccupied by the potential } \\
\text { countermeasures which they would face if the evaluation } \\
\text { results are unsatisfactory (dismissal, salary / incentives cut } \\
\text { etc.) }\end{array}$ \\
\hline R5 & $\begin{array}{l}\text { Evaluator's lack of } \\
\text { knowledge }\end{array}$ & $\begin{array}{l}\text { The evaluator does not apply the assessment methodology } \\
\text { accordingly/ conducts the evaluation process poorly/ } \\
\text { irrelevant results. } \\
\text { The evaluator is not qualified for undertaking employees } \\
\text { performance appraisals. }\end{array}$ \\
\hline R6 & $\begin{array}{l}\text { Lack of relevance of } \\
\text { evaluation } \\
\text { regarding criteria } \\
\text { tasks }\end{array}$ & $\begin{array}{l}\text { The evaluation methodology is not suited for particular job } \\
\text { categories, which have specific assessment requirements } \\
\text { (e.g. high risk jobs: air traffic controllers, mining, handling } \\
\text { dangerous substances, services which involve exposure to } \\
\text { dangerous behavior etc.) }\end{array}$ \\
\hline $\mathrm{R} 7$ & Evaluator's subjectivity & $\begin{array}{l}\text { The system of appraisal (performance ratings) is too strict, } \\
\text { hence the evaluators should provide input based on meetings } \\
\text { and discussions. } \\
\text { The evaluator favours an employee, while mistreating other } \\
\text { employees (a biased review of employees performance due } \\
\text { to lack of evaluator's independence). }\end{array}$ \\
\hline $\mathrm{R} 8$ & $\begin{array}{l}\text { The length of the } \\
\text { evaluation process }\end{array}$ & $\begin{array}{l}\text { Process timeline is ineffective, as it is either too long (it } \\
\text { becomes irrelevant as the employee becomes weary) or too } \\
\text { quick (not enough time spent for establishing key and/ or } \\
\text { emerging issues related to employees job performance) }\end{array}$ \\
\hline R9 & $\begin{array}{l}\text { The evaluation is not a } \\
\text { regulatory requirement }\end{array}$ & $\begin{array}{l}\text { The performance appraisal is not performed on a regular } \\
\text { basis, hence no continuity of the process. }\end{array}$ \\
\hline R10 & Litigation & $\begin{array}{l}\text { The employee instigates lawsuit considering the } \\
\text { performance appraisal is unfair/ based on discriminatory } \\
\text { criteria. }\end{array}$ \\
\hline
\end{tabular}

Therefore, a dysfunction of HR assessment sub-process introduces flaws when designing employees' development programs. This may result in an inefficient training program due to lack of knowledge regarding the real features of the person's traits. 


\subsection{Conceptual model of human resource performance evaluation process}

The performance evaluation sub-process starts due to trigger "New job/ Periodical evaluation due time", which enables to "Identify evaluation's objectives" (Fig.2). The assessment objectives may be related to the labour system within the enterprise (people, physical environment, social connections, technology etc.), to new work methods/ techniques/ instruments etc.

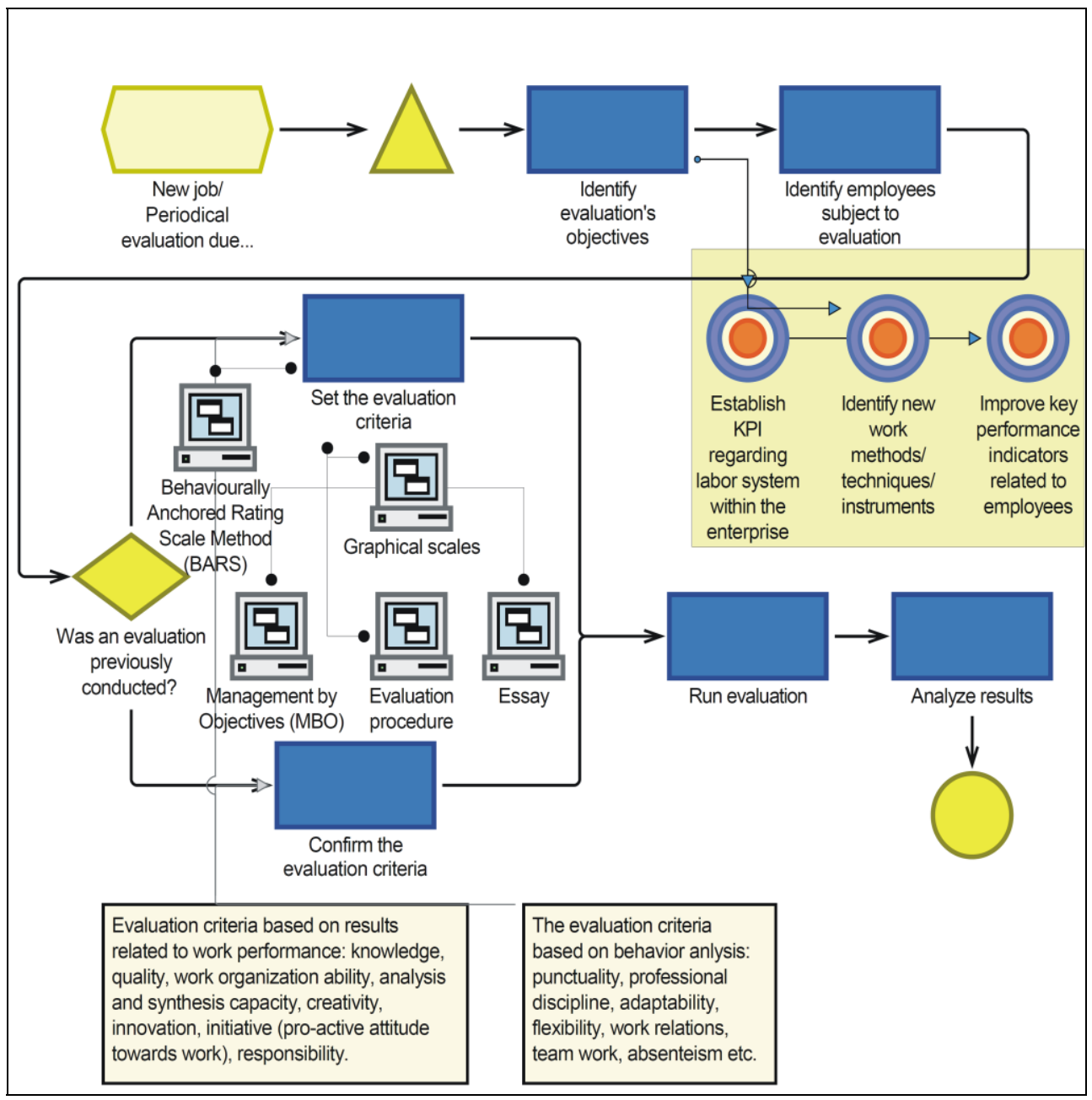

Fig. 2. Conceptual model of human resource performance evaluation process.

Based on the assessment objectives, a specific category of employees is selected in order to run the performance evaluation. Therefore, the entity conducting the process should choose and apply the proper methodology depending on the enterprises requirements. The evaluation criteria reveal different aspects regarding the human resource behaviour within the labour system, hence the choice regarding the methodology which should be used (Behaviourally Anchored Rating Scale Method-BARS, Graphical scales, Management by Objectives $\mathrm{MBO}$, essay, internal performance evaluation procedure etc.) is directly dependent on the type of information and knowledge required by the enterprise. The human resource 
evaluation methods have different applicability area, hence in Table 2 the authors have emphasized the limitations of the three main methodologies used for performance appraisal by performing a comparative analysis regarding the use of graphical scales, Behaviourally Anchored Rating Scale Method and Management by Objectives.

Table 2. Comparative analysis of human resource performance evaluation methodologies.

\begin{tabular}{|l|c|c|c|l|}
\hline \multicolumn{1}{|c|}{ Criteria } & Scales & BARS & MBO & \multicolumn{1}{|c|}{ Risk } \\
\hline $\begin{array}{l}\text { Standardized } \\
\text { questionnaire }\end{array}$ & $\mathrm{x}$ & $\mathrm{x}$ & - & $\begin{array}{l}\text { Lack of precision (the } \\
\text { questionnaire's content lack of } \\
\text { flexibility) }\end{array}$ \\
\hline Action-oriented & - & $\mathrm{x}$ & $\mathrm{x}$ & $\begin{array}{l}\text { Time-consuming for developing } \\
\text { plans for performance improvement }\end{array}$ \\
\hline $\begin{array}{l}\text { Based on critical } \\
\text { incidents }\end{array}$ & - & $\mathrm{x}$ & - & $\begin{array}{l}\text { Requires more effort in order to } \\
\text { identify extreme (positive/ negative) } \\
\text { behavioural cases }\end{array}$ \\
\hline $\begin{array}{l}\text { Evaluation criteria } \\
\text { developed based on } \\
\text { manager-employees } \\
\text { interaction }\end{array}$ & - & - & $\mathrm{x}$ & $\begin{array}{l}\text { Unrealistic targets for human } \\
\text { resource performance (optimistic } \\
\text { approach when defining evaluation } \\
\text { objectives) }\end{array}$ \\
\hline Based on real facts & $\mathrm{x}$ & $\mathrm{x}$ & $\mathrm{x}$ & $\begin{array}{l}\text { Lack of knowledge regarding } \\
\text { employee's potential behaviour in a } \\
\text { specific scenario }\end{array}$ \\
\hline $\begin{array}{l}\text { Focused on providing } \\
\text { rewards }\end{array}$ & - & $\mathrm{x}$ & $\mathrm{x}$ & $\begin{array}{l}\text { The employees are focused more on } \\
\text { evaluation results rather than work } \\
\text { itself. }\end{array}$ \\
\hline
\end{tabular}

The risks related to human resource performance evaluation methodologies highlight the problems which enterprises may encounter when conducting this particular process, due to high diversity of factors which define the employees' work results - knowledge, analysis and synthesis capacity, creativity, innovation, initiative (pro-active attitude towards work), responsibility, punctuality, professional discipline, adaptability, flexibility etc.

\section{Conclusions and future research directions}

The enterprises' need for predicting the employees' performance has generated the high interest for scholars to develop HR assessment methodologies in order to prevent and/ or diminish the risks which may encounter both the employee and the employer when conducting performance appraisals. Therefore, the authors propose as future research direction the development of an innovative assessment method based on measuring the electromagnetic field of human being using ElectroPhotonic Imaging device and software [12].

The main benefits of this new method lie in the ability to run "on-the-job" measurements, hence conducting quantitative analysis, especially regarding highly stressful jobs. Therefore, this method will provide valuable input related to employees who require high stress resilience, an increased capacity to adapt to complex situations on a daily basis, a high level of emotional tension etc.

By examining the relationship between the results retrieved by ElectroPhotonic Imaging device and the employees' personality traits, the method allows for long-term performance enhancement and an overall organizational working system improvement. 


\section{References}

1. E.A.M.E. Maycock, E. Allaputa, G.D., Waripanye, R. Geraghty, S., Chikafa, J. of Bus. and Man. 16, 6 (2015), http://iosrjournals.org/iosr-jbm/papers/Vol17-issue6/Version-1/B017611421.pdf

2. J.S. Itika, Fundamentals of human resource management (University of Groningen, 2011), https://openaccess.leidenuniv.nl/bitstream/handle/1887/22381/ASC-075287668-303001.pdf? sequence $=2$

3. A.A. Purcărea, D.C. Şerban, O.I. Negoiţă , O. D. Negoiţă, Revue Européenne Du Droit Social, 20, 3 (2013)

4. http://www.businessdictionary.com/definition/human-performance.html

5. A.A. Purcărea, Human Resource Management -Training (PUB, 2012)

6. R.L. Mathis, P.C. Nica, C. Rusu, Managementul resurselor umane (Editura Economica, 1997)

7. A.A. Purcărea, Management modern (Editura Niculescu, 1998)

8. http://www.simplehrguide.com/performance-management-risks.html

9. Delloite, Risk committee performance evaluation (Deliotte\&Touche, 2014), https://www2.deloitte.com/content/dam/Deloitte/za/Documents/governance-riskcompliance/ZA_RiskCommitteePerformanceEvaluation_24032014.pdf

10. http://www.talentculture.com/conduct-a-performance-appraisal-with-minimal-risk/

11. http://legacy.juniata.edu/services/hresources/documents/WhitePaperPerformanceReviewEvaluati ons.pdf.

12. A. Torp, Z.I. Marosy, A.A. Purcărea, SEA 2, 3 (5) (2014) 